DOI: $10.15503 /$ onis2011-11-21

\title{
ETYKa CNÓT, JAKO ODRADZAJĄCY SIĘ PARADYGMAT FILOZOFII MORALNEJ
}

\author{
BARTOSZ FINGAS \\ bfingas@wp.pl
}

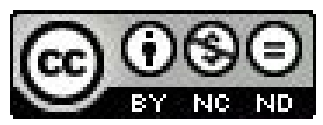

Słowo „cnota” brzmi we współczesnym, potocznym języku archaicznie. Powoduje ono wiele różnych skojarzeń, ale niewielu używa go na co dzień w kontekście dociekań moralnych. Podobnie jest w środowisku współczesnych filozofów. Filozofowie zazwyczaj znają termin „,cnota”, ale używają go zwykle w kontekście historycznym - gdy mówią np. o etyce w starożytności i średniowieczu. Przyczyną tego stanu rzeczy są wpływy filozofii nowożytnej na współczesną. Aż do końca XX wieku w myśli etycznej dominowały paradygmaty wyznaczone przez takich myślicieli, jak Immanuel Kant, Jeremy Bentham, John Stuart Mill, czy Fryderyk Nietsche. Obecnie sytuacja coraz bardziej zaczyna się zmieniać, ponieważ etyka cnót coraz częściej stanowi punkt wyjścia dociekań moralnych.

W wyjaśnieniu tego stanu rzeczy pomocna jest teoria współczesnego filozofa Alasdaira MacIntyre'a. Obserwując współczesne spory natury moralnej doszedł on do oczywistego wniosku, że są one niekonkluzywne. Oznacza to, że mimo wielu toczonych dyskusji i wysuwanych argumentów filozofowie nie są w stanie przekonać swoich oponentów do własnych racji i wydać ostatecznego, racjonalnego werdyktu. Zastanawiając się, czemu tak jest, MacIntyre doszedł do wniosku, że kluczem do wyjaśnienia tego stanu rzeczy jest teoria analogiczna do teorii paradygmatów Thomasa Kuhna. Kuhn był filozofem, który stwierdził, że w historii nauki od Arystotelesa, poprzez Ptolemeusza, Galileusza, Einsteina aż do współczesności nie ma ciągłości. Nauka nie rozwija się, jako ciąg logicznie po sobie następujących odkryć, ale powstaje w ramach poszczególnych paradygmatów. Paradygmat to zbiór pojęć i założeń na bazie których rozwija się nauka. Paradygmaty zmieniały się w trakcie rozwoju nauki, co oznacza, że nie można porównać ze sobą teorii pochodzących z dwóch różnych paradygmatów - są one bowiem nieporównywalne i niewspółmierne ${ }^{1}$.

Zdaniem Alasdaira MacIntyre'a podobna sytuacja zachodzi w dociekaniach natury moralnej². Spory etyczne są nierozstrzygalne ze względu na to, że osoby je prowadzące operują różnymi paradygmatami, które są niewspółmierne. Racjonalne porozumienie pomiędzy przedstawicielami różnych paradygmatów jest niemożliwe, ponieważ inaczej rozumieją oni poszczególne pojęcia, wychodzą z odrębnych założeń lub też dążą do innych celów. Klasyfikację takich paradygmatów w XIX i XX w. MacIntyre podał i opisał w książce Trzy antagonistyczne wersje dociekań moralnych ${ }^{3}$. Pierwszy z nich nosi nazwę encyklopedycznego, ponieważ najważniejszym tekstem dla tej tradycji była według MacIntyre’a IX edycja Encyklopedii Brytannika. Prezentuje ona bowiem oświeceniowy punkt widzenia, który zakładał, że wszyscy ludzie dysponują rozumem pozwalającym poznać absolutne i uniwersalne zasady działania ludzkiego. Druga tradycja badań moralnych wywodzi się od Fryderyka Nietschego, a w szczególności jego dzieła Z genealogii moralności. Akcentuje ona twórczy charakter dociekań moralnych (etykę się tworzy, a nie odkrywa) oraz perspektywizm i relatywizm. Trzecia tradycja została odrodzona w drugiej połowie XIX w. za sprawą encykliki Leona XIII Aeterni Patris. Swoimi korzeniami sięga jednak filozofii Arystotelesa i Tomasza z Akwinu -

T. Kuhn, Struktura rewolucji naukowych, Warszawa 2009.

A. MacIntyre, Dziedzictwo cnoty, Warszawa 1996, s. 29-32.

Tenże, Trzy antagonistyczne wersje dociekań moralnych: Etyka, Genealogia i Tradycja, Warszawa 2009. 
dlatego nosi nazwę tradycji tomistycznej. Klasyfikację MacIntyréa można rozszerzyć wyróżniając w obrębie tradycji oświeceniowej etykę deontologiczną Kanta i utylitaryzm Milla.

Pojęcie cnoty (gr. arete) pojawia się już w dziełach epickich Homera. Oznacza ono cechy pozytywne, zalety oraz doskonałość $\mathrm{w}$ określonej dziedzinie. W szerszym znaczeniu termin ten odnosił się zarówno do cech ludzi, jak i zwierząt i bogów. W węższym, częściej używanym sensie arete to cechy i doskonałości przysługujące najlepszym obywatelom, czyli arystokracji. Stąd też wywodzi się termin arystokracja - aristos jest stopniem najwyższym od słowa "dobry"'. Arete odnosiło się głównie do zalet fizycznych i często wiązało się z walecznością - oznaczało np. siłę i zręczność wojownika. Za pomocą tego terminu oddawano również odwagę, męstwo, szybkość, spryt i przebiegłość. Nie były one jednak rozumiane, jak cechy moralne.

Filozofowie greccy doby klasycznej dalej rozumieli cnotę (arete), jako dobro i doskonałość, ale odnosili ją do moralności. Platon w dialogu zatytułowanym Państwo przedstawia klasyfikację czterech cnót kardynalnych, które uznawano za podstawowe jeszcze w czasach średniowiecznych. Koncepcja ta przetrwała również we współczesnym nauczaniu Kościoła katolickiego ${ }^{6}$. Platon wyróżnił następujące cnoty: roztropność, męstwo, umiarkowanie i sprawiedliwość. By wyjaśnić na czym one polegają posłużył się on porównaniem cnotliwego człowieka do idealnego państwa. Na jego czele powinien stać władca, którego główną cechą miała być roztropność, czyli mądrość w rządzeniu państwem. Męstwo powinno cechować żołnierzy, którzy tego państwa mieli bronić i być mu oddani. Umiarkowanie miało być najważniejszą cnotą wytwórców, czyli ludzi zaopatrujących państwo w rozmaite dobra. Natomiast sprawiedliwość miała przysługiwać wszystkim trzem klasom społecznym idealnego państwa. Za jej sprawą każdy powinien znać swoje miejsce w hierarchii społecznej i robić to, do czego najlepiej się nadaje i do czego został wyznaczony. Tak, jak części państwa miały specyficzne dla siebie cnoty, tak również miały je poszczególne części człowieka. Głowa powinna cechować się roztropnością, czyli mądrością w kierowaniu swoim życiem. Męstwo miało przysługiwać torsowi, jako symbolowi waleczności i odwagi, natomiast umiarkowanie miało być właściwe części pożądliwej człowieka lokalizowanej w podbrzuszu?

Naukę o cnotach w sposób bardziej pełny i systematyczny opisał uczeń Platon, Arystoteles. W czasach hellenistycznych również powstawały teorie cnót,jednak historia myśli etycznej pokazała, że to jednak arystotelesowska, a nie stoicka czy jakakolwiek inna miała największy wpływ na etykę cnót. Również współcześni autorzy zajmujący się tą problematyką najczęściej odwołują się właśnie do Arystotelesa i Tomasza z Akwinu. Ze względu na ograniczenia ilościowe niniejszej pracy pomięte zostaną pozostałe teorie. Z tych samych powodów etyka Arystotelesa i św. Tomasza będzie traktowana, jako jedna teoria. Poglądy Akwinaty różnią się od Arystotelesa w kilku mniej lub bardziej ważnych kwestiach, jednak różnice te mają charakter rozwinięcia, uszczegółowienia, uzupełnienia oraz dopasowania do innych warunków historycznych. Mówiąc językiem Macintyre’a obydwie teorie należały do tego samego paradygmatu. $Z$ tego powodu pozwoliłem sobie na to uproszczenie.

\footnotetext{
W. Jaeger, Paideia. Formowanie człowieka greckiego, Warszawa 2001, s. 52-53.

Tamże, s. 53-54. Por. A. MacIntyre, Dziedzictwo..., dz. cyt., s. 228-230.

Katechizm Kościoła Katolickiego, Poznań 1994, art. 1805-1809, http://www.katechizm.opoka.org.pl/, 12.11.2010.

Platon, Państwo, Kęty 2003, s. 428-430. Por. G. Reale, Historia filozofii starożytnej, t. 2, Lublin 1996, s. 291-300.

W Dziedzictwie cnoty MacIntyre twierdzi, że chrześcijańska koncepcja cnót Tomasza w bardzo dużym stopniu różni się od Arystotelesowskiej (A. MacIntyre, Dziedzictwo..., dz. cyt., s. 322, 329-330). Jednak później pisał on: „W Afrer Virtue nie wiedziałem jeszcze - $w$ tej mierze, jak wiem teraz - tego, jak Tomasz z Akwinu wzbogacił i przywrócił tradycję [arystotelizmu - J. Z.] i nadał jej ostateczny kształt". A. MacIntyre, A Partial Response to my Critics, [w:] J. Horton, S. Mendus (red.), After MacIntyre. Critical Perspectives on the Work of Alasdair MacIntyre, Cambridge 1994, s. 298; cyt. za: J. Zdybel, Wprowadzenie do wydania polskiego, [w:] A. MacIntyre, Trzy antagonistyczne..., dz. cyt., s. 14.
} 
Arystoteles w II księdze Etyki Nikomachejskiej zdefiniował cnotę (ti. dzielność etyczną w przekładzie Danieli Gromkiej) następująco: „Dzielność etyczna jest trwałą dyspozycją do pewnego rodzaju postanowień, polegająca na zachowaniu właściwej ze względu na nas średniej miary, którą określa rozum, i to w sposób, w jaki by ją określił człowiek rozsądny" ${ }^{\prime \prime}$. W definicji tej można wyróżnić cztery elementy.

Pierwszym jest trwała dyspozycja, która jest pewną jakościa, cechą. Dzięki niej człowiek $\mathrm{z}$ łatwością postępuje w określony sposób. Dyspozycja jest pewną potencjalnością, która trwale w nas tkwi, i którą możemy wykorzystać, gdy tylko nadejdzie taka okazja. Można tutaj podać przykład grania na instrumencie muzycznym ${ }^{10}$ : jeśli ktoś nie potrafi na nim grać lub potrafi w słabym stopniu, czynność grania sprawia mu trudność. Jeśli nabył już trwałą dyspozycję do grania na instrumencie muzycznym, przychodzi mu to z łatwością. Muzyk posiada ją nawet, gdy w danej konkretnej chwili nie gra na żadnym instrumencie. Nie oznacza to jednak, że nie posiada tej umiejętności. Podobnie człowiek może posiadać trwałą dyspozycje, jaką jest m.in. męstwo, mimo że w danej chwili nie ma okazji, by ją wykorzystać.

Drugi element definicji mówi, że trwała dyspozycja dotyczy postanowień. Oznacza to, że cnota odnosi się do wolnych wyborów człowieka. Z twierdzenia tego można wywnioskować, że z cnotą (lub z jej przeciwieństwem - wadą) mamy do czynienia tam, gdzie w grę wchodzą wolne wybory ludzi. Jak pisze Arystoteles, cnota nie odnosi się do namiętności (emocji), ponieważ „w gniew lub strach popadamy niezależnie od postanowienia" ${ }^{\prime 11}$. Dopiero to, $\mathrm{w}$ jaki sposób ustosunkujemy się do tych emocji, czyni nas osobami posiadającymi cnoty lub wady. W związku z tym, że tylko istota wolna, czyli człowiek, może dokonywać postanowień, nie można powiedzieć, że zwierzę posiada arete, jak to czynił Homer. Zwierzęta postępują zawsze zgodnie ze swoimi namiętnościami, czy jakbyśmy inaczej powiedzieli, instynktami. Tymczasem dla człowieka nie zawsze jest dobre postępowanie zgodne z tym, co dyktują nam emocje. O człowieku nieopanowanym mówimy, że miotają nim namiętności. Tymczasem cnota wprowadza w zachowanie człowieka element racjonalny; panując na emocjami można osiągnąć więcej niż zwierzę natychmiastowo reagujące na bodźce zgodnie ze swoim instynktem.

Trzeci element definicji dotyczy właściwej ze względu na nas średniej miary. Wiąże się to ze słynną doktryną „złotego środka”. Arystoteles twierdzit, że dany czyn możemy wykonać z pewnym nadmiarem, niedostatkiem lub umiarem, który jest pożądanym „środkiem”. Klasycznym przykładem jest tu cnota odwagi. Jej przeciwnościami są: tchórzostwo, które jest niedostatkiem odwagi, oraz brawura, która jest nadmiarem odwagi ${ }^{12}$. Podobnie jest z innymi cnotami: hojnościa, umiarkowaniem, itd. Wniosek, który z tego wypływa jest taki, że źle można postępować na wiele sposobów, a dobrze tylko na jeden. Arystoteles zaznacza jednak, że od tej zasady są wyjątki: są to tak zwane czyny co do rodzaju złe. Przykładami takich czynów są cudzołóstwo, kradzież i morderstwo. Nie da się bowiem powiedzieć, że cudzołożyć lub mordować trzeba umiarkowanie, a wystrzegać się ich nadmiaru i niedostatku. Każdy kto to czyni, niezależnie od czasu, miejsca i okoliczności zawsze popełnia zły uczynek ${ }^{13}$.

Ważne jest doprecyzowanie, że średnią miarę wyznacza się ze względu na nas. Oznacza to

\footnotetext{
$9 \quad$ Arystoteles, Etyka Nikomachejska, [w:] tenże, Dzieła wszystkie, t. 5, Warszawa 1996, 1106b-1107a.

10 Tego rodzaju przykładami często posługuje się Arystoteles. Por. tamże, 1103ab.

Tamże, 1106a.

12 Por. W. Galewicz, Wstęp ttumacza, [w:] św. Tomasz z Akwinu, Traktat o cnotach, Kęty 2006, s. 42-46.

Arystoteles, Etyka nikomachejska..., dz. cyt., 1107a. Por. M. Głowala, Dlaczego pewnych rodzajów rzeczy nigdy nie wolno robić? Malum ex genere i bytowość uczynku ludzkiego, „Studia Philosophica Wratislaviensa” 2010, nr 3, s. 137-148.
} 
zrelatywizowanie uczynków do konkretnej osoby, z jej konkretnymi zdolnościami, namiętnościami, cnotami i wadami. To, co dla jednej osoby może być właściwym uczynkiem, dla innej może być nadmiarem lub niedostatkiem. Tak jest na przykład z hojnością. Dla biednej osoby ofiarowanie określonej sumy będzie rozrzutnościa, podczas gdy dla osoby bogatej ofiarowanie tej samej kwoty będzie skąpstwem. Innym przykładem jest umiarkowanie w spożywaniu alkoholu. Jeśli ktoś ma większe skłonności do upijania się, w danych okolicznościach powinien wypić mniej lub wcale, podczas gdy osoba nie mająca problemów z alkoholem może wypić więcej. Wyjątkiem jest tu cnota sprawiedliwości, która nie jest średnią miarą ze względu na nas, ale ze względu na drugą osobę. Gdy jesteśmy komuś winni określoną sumę pieniędzy, powinniśmy ją zwrócić bez względu na to czy jesteśmy biedni, czy bogaci ${ }^{14}$.

Ostatnim elementem definicji cnoty Arystotelesa jest stwierdzenie, że właściwy środek określa rozum, w taki sposób, w jaki by ją określił człowiek rozsądny. To, co jest cnotliwe osądza rozum w przeciwieństwie do namiętności, nad którymi powinien panować. Człowiek posiada pełną cnotę wtedy, gdy samodzielnie wydaje sąd rozumu praktycznego, którego wnioskiem jest prawidłowe działanie. Można jednak działać w sposób dobry opierając się na sądzie kogoś innego, np. za pomocą czyjejś rady. Oznaką roztropności jest zwrócenie się o radę do osoby posiadającej mądrość praktyczna, gdy sami nie wiemy, jak powinniśmy postąpić.

W trochę inny sposób zdefiniował cnotę Tomasz z Akwinu. Pisał on, że „cnota jest dobrą jakością umysłu, dzięki której żyjemy w sposób prawy, którą nikt nie posługuje się źle i którą Bóg sprawia w nas bez nas"15. Po bliższym przyjrzeniu się tej definicji okazuje się, że jest to jedynie powtórzenie i uzupełnienie tego, co pisał o cnocie Arystoteles. To, co Arystoteles nazywał dyspozycja jest pewnego rodzaju jakością (cechą), o której pisał Akwinata. Podmiotem (czy jakbyśmy powiedzieli - „nośnikiem”) cnoty jest umysł, który zawiera w sobie władzę wydawania postanowień i osądzania rozumowego, o których pisał Arystoteles.

Istotnym uściśleniem definicji pochodzącej z Etyki Nikomachejskiej jest to, że cnotą nie można posługiwać się w sposób zły. Jest to podkreślenie tego, co Arystoteles oddawał za pomocą zdefiniowania cnoty, jako właściwej miary, którą określa słuszny sąd. Z twierdzenia Tomasza wynika ponadto, że wszystkie cnoty są ze sobą w pewien sposób powiązane. Jeśli np. ktoś zachowa się w sposób hojny udzielając jałmużny żebrakowi, ale zrobi to tylko po to, by uzyskać jego przychylność w jakimś niegodnym celu, nie będzie to czyn dobry. W tym wypadku akt hojności nie będzie cnota, ponieważ został wykorzystany w sposób zły - a z definicji Tomasza wynika, że tak być nie może.

Równie ważnym uzupełnieniem definicji Stagiryty jest stwierdzenie, że dzięki cnocie żyjemy w sposób prawy. Arystoteles pisał, że celem życia człowieka jest szczęście, które utożsamiał z prowadzeniem dobrego życia. To zaś jest tym samym, co życie zgodne z cnotami. Stwierdzenia tego nie umieścił jednak z swojej definicji cnoty, co uczynił Akwinata.

Tomasz dodaje również, że przyczyną sprawczą cnoty jest Bóg, który sprawia, że stajemy się cnotliwi niezależnie od nas samych. Dalej wyjaśnia jednak, że ta część definicji odnosi się jedynie do cnót wlanych, czyli teologalnych, a nie nabytych, czyli tych, o których pisał Arystoteles. Nie należy zapominać, że św. Tomasz był przede wszystkim teologiem, więc wspomnienie cnót nadprzyrodzonych, których istnienie rozważa teologia, nie powinno dziwić. Ponieważ nie dotyczą one jednak namysłu filozoficznego nad cnotami, ich opis nie będzie rozwijany.

Oprócz definicji warto przyjrzeć się procesowi nabywania cnót. Już sam fakt, że cnoty się nabywa, wskazuje na to, że nie są one wrodzone. Jak pisał Arystoteles: „nic bowiem z tego, co jest

14 Por. W. Galewicz, Wstęp..., dz. cyt., s. 46-50.

15 Św. Tomasz z Akwinu, Traktat o cnotach, Kęty 2006, I-II q. 55, art. 4. 
wrodzone, nie daje się zmienić dzięki przyzwyczajeniu; tak np. kamień, z natury w dół spadający, nie da się przyzwyczaić do wznoszenia się w górę" ${ }^{\prime \prime 16}$.Z drugiej strony człowiek na wrodzoną zdolność do nabywania trwałych dyspozycji, które istnieją w nim potencjalnie ${ }^{17}$. Dopiero jednak działanie aktualizuje to, co w człowieku istnieje potencjalnie ${ }^{18}$.

Człowiek nie staje sięjednak cnotliwy, czyli dobry, za sprawąjednego dobrego uczynku. Jak zauważył Arystoteles, ,jedna bowiem jaskółka nie stanowi o wiośnie ani jeden dzien'” ${ }^{\prime 19}$. Dobre uczynki przyzwyczajają do dobrego postępowania, dzięki czemu człowiek staje się cnotliwy. Można powiedzieć, że dobre postępowanie wchodzi wtedy człowiekowi w krew. Człowiek staje się sprawiedliwy poprzez wykonywanie sprawiedliwych uczynków $w^{20}$, tak samo, jak grając na pianinie staje się dobrym pianistą. Trudno jednak postępować sprawiedliwie nie posiadając cnoty sprawiedliwości. Tkwi w tym pewien pozorny paradoks, ponieważ aby posiadać cnotę sprawiedliwości trzeba postępować sprawiedliwie, ale żeby postępować sprawiedliwe trzeba już być cnotliwym ${ }^{21}$. To, że jest to paradoks pozorny pokazuje przykład muzyka, który uczy się grając na instrumencie. Gra on nie posiadając jeszcze umiejętności grania, jednak im więcej się stara grać poprawnie, tym szybciej tę umiejętność nabywa. Podobnie jest z cnotą: jeśli ktoś nie posiada cnót, dobre uczynki przychodzą mu z trudem i musi włożyć wiele starań i wysiłku, by taki czyn wprowadzić w życie. Dopiero po przyzwyczajeniu do wykonywania dobrych uczynków można powiedzieć, że dana osoba jest cnotliwa. Kryterium tego, czy ktoś jest cnotliwy jest jego przyjemność, którą czerpie z wykonywania dobrych uczynków ${ }^{22}$. Jeśli danej osobie z łatwością przychodzi wykonywanie czynów sprawiedliwych i czerpie z tego radość, jest to oznaka, że nabył on cnotę sprawiedliwości. Podobnie jest z męstwem, umiarkowaniem i innymi cnotami. Tutaj również nasuwa się analogia z grą na instrumencie. Początkowo gra na pianinie przychodzi z trudem, nauka jest mozolna i nie sprawia zbyt wiele przyjemności. Jednak w momencie, gdy ktoś uzyskał bardzo wysoki stopień umiejętności gry, sprawia mu ona wiele przyjemności.

W tym kontekście łatwo zrozumieć relację jaka zachodzi między dobrymi uczynkami a szczęściem. Zgodnie z etyką cnót, celem człowieka jest dążenie do doskonałości, a w tym przede wszystkim do doskonałości moralnej i intelektualnej. Z kolei urzeczywistnienie tej doskonałości czyni ludzi szczęśliwymi, ponieważ dobre życie sprawia radość i przyjemność. Dlatego Arystoteles utożsamia dobre życie z życiem cnotliwym i szczęśliwym ${ }^{23}$.

To, że etyka cnót jest różnym od współczesnych paradygmatem uprawiania etyki pokazuje porównanie jej z nowożytnymi i współczesnymi koncepcjami z zakresu filozofii moralnej. Jak już wspomniałem Alasdair MacIntyre wyróżnił paradygmat oświeceniowy i nietzscheański. Za pogląd będący konsekwencją porażki paradygmatu oświeceniowego i mający pewne cechy wspólne z nietzscheanizmem uznał on emotywizm (ściśle mówiąc jest on konsekwencją pozytywizmu i na gruncie tej filozofii się rozwijał). Krytykę tego nurtu zawarł on w książce, która uchodzi za jedno z najważniejszych dzieł odnawiających etykę cnót $t^{24}$.

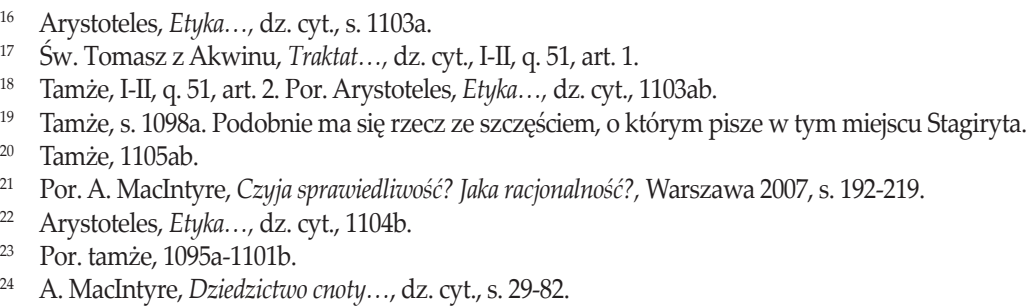


Emotywizm jest koncepcja, która odmawia wszelkiej racjonalności i obiektywności sądom wartościującym i moralnym. Skoro jednak fakt wydawania takich sądów i postępowania zgodnie z nimi jest niepodważalny, wywnioskowano, że sądy te są tylko i wyłącznie wyrazem preferencji, upodobań i uczuć2 ${ }^{25}$. Już ta skrótowa charakterystyka wskazuje, że emotywizm zupełnie inaczej traktuje zjawiska o charakterze moralnym, niż etyka cnót. Jeśli etyka jest jedynie kwestią upodobania, wszelkie dyskusje i oceny zachowań moralnych są pozbawione sensu. Jak pisze MacIntyre, ta doktryna etyczna nie jest również zdolna do czynienia wielu rozróżnień czynów moralnych, co prowadzi do kryzysu kultury. Przykładem jest tutaj niemożliwość odróżnienia zachowań manipulacyjnych od niemanipulacyjnych. Oznacza to, że na gruncie emotywizmu nie można określić, czy ktoś traktuje człowieka jako środek do swoich partykularnych celów, czy też szanuje czyjąś godność i prawo do autonomii²6.

Różnice emotywizmu i etyki cnót wydają się oczywiste. Emotywizm pozbawia sensu kształtowanie charakteru, ponieważ rozróżnienie na sferę emocjonalną i moralną jest niemożliwe. Etyka cnót głosi, że to właśnie rozum ma panować nad emocjami. Natomiast na gruncie omawianej doktryny emocje stanowią już ostateczne kryterium działań moralnych. Na gruncie tej doktryny trudno też powiązać dobre uczynki ze szczęśliwym życiem. Każdy człowiek posiada jakiś stosunek emocjonalny do różnych uczynków, więc ten stosunek nie może wpływać na szczęście człowieka. Mimo że MacIntyre twierdzi, że emotywizm stanowi duże zagrożenie dla kultury, to obecnie wydaje się, że staje się on stanowiskiem coraz bardziej marginalnym, dlatego warto przyjrzeć się dwóm doktrynom etycznym, których popularność nie słabnie w naszych czasach.

Są to mianowicie dwie doktryny wyrastające z oświeceniowego, albo jakby powiedział MacIntyre, encyklopedycznego paradygmatu: utylitaryzm i etyka deontologiczna. Ich wspólną cechą jest wiara w możliwość znalezienia zasady, która abstrahując od wszelkich konkretnych, przygodnych okoliczności będzie w stanie rozstrzygnąć, jak powinniśmy się zachować. Właśnie ta wiara w uniwersalność rozumu, który wyznacza absolutne zasady postępowania, decyduje o ich przynależności do paradygmatu oświeceniowego.

Czym są te doktryny dość barwnie przedstawił Max Weber. Pisał on, że wszystkie doktryny etyczne można podzielić na dwie części: etykę przekonań i etykę obowiązkư ${ }^{27}$. Tę pierwszą nazywa etyką świętego, ponieważ dzieli ona ludzkie czyny na dobre i złe oraz bezwzględnie, nie zważając na okoliczności, nakazuje czynić te pierwsze. Dlatego „święty” chcąc zachować czyste sumienie, nie popełni nigdy czynu złego, który może mieć dobre konsekwencje. Z kolei polityk będąc zmuszony do kalkulacji konsekwencji swoich działań, nie zważa na to, czy jego czyny są dobre czy złe, ale ocenia je tylko zgodnie z kryterium ich skutków ${ }^{28}$. Z tego powodu święty nigdy nie skłamie, nawet jeśli będzie miało to dobre konsekwencje, a polityk skłamie zawsze, jeśli tylko uzna, że dobro, które tym samym osiagnie, będzie przewyższało zło kłamstwa.

Etyka świętego obrazuje tu etykę deontologiczna, której najważniejszym przedstawicielem był Kant. Z kolei etyka polityka to konsekwencjalizm (nazywany utylitaryzm), za którym opowiadał się Jeremy Bentham i John Stuart Mill. Jak pisała Natasza Szutta, współcześnie doktryny

25 Tamże, s. 39

26 Tamże, s. 60-62.

27 Twierdzenie to jest jednak nieścisłe, ponieważ, jak pokazuje przykład etyki cnót, istnieją doktryny, które wymykają się temu podziałowi. Dlatego twierdzenie to odnosi się jedynie do nowożytnej filozofii moralnej. Por. R. Spaemann, Kto i za co jest odpowiedzialny? Krytyczne spojrzenie na odróżnienie etyki przekonań i etyki odpowiedzialności, [w:] tenże, Granice. O etycznym wymiarze działania, Warszawa 2006, s. 392-419.

28 Tamże, 392-399. 
te dominują w filozofii moralnej, jednak duże zainteresowanie etyką cnót powoduje, że staje się ona poważnym konkurentem tych współczesnych etyk ${ }^{29}$.

Porównując etykę cnót z deontologią i utylitaryzmem warto zauważyć, że już sam przedmiot etyki jest według niej inny, niż to przedstawiają doktryny oświeceniowe. Te ostatnie za cel swojego namysłu stawiają pytanie: Co powinienem czynić? Tymczasem istotą etyki cnót jest zagadnienie: Jakiego rodzaju człowiekiem powinienem się stać? ${ }^{30}$. Można zauważyć to już podczas przedstawionych wyżej definicji cnoty: wskazywały one, że przedmiotem etyki jest człowiek i jego trwałe dyspozycje, czyli, jakbyśmy dzisiaj powiedzieli - charakter. Pojedyncze uczynki są interesujące tylko o tyle, o ile składają się na proces nabywania cnoty ${ }^{31}$.

Etyka cnót inaczej przedstawia źródło wiedzy o czynach dobrych. Nie szuka ona, jak np. deontologizm Kanta, uniwersalnych formuł jasnych dla każdego rozumnego człowieka, lecz kładzie nacisk na rolę wzoru i autorytetu moralnego. Obserwując i naśladując osoby cnotliwe, wyrabiamy w sobie phronesis, czyli roztropność, która mówi nam, co powinniśmy robić w danych, konkretnych okolicznościach. Nie da się bowiem każdej, różnorodnej sytuacji umiejscowić w jednym ogólnym schemacie działania. A tego, co w danej sytuacji jest roztropne, uczą nas osoby dysponujące doświadczeniem życiowym i wiedzą praktyczna, którą rozpoznajemy u innych po tym, czy prowadzą oni dobre życie ${ }^{32}$.

Stąd bierze się szerokie rozumienie wiedzy w etyce cnót. Oprócz wiedzy teoretycznej i opisowej istnieje jeszcze wiedza życiowa, którą zdobywamy poprzez doświadczenie i kształtowanie cnót - o tej prawdzie filozofowie nowożytni najwidoczniej zapomnieli33 .

Kolejnym zagadnieniem różniącym omawiane doktryny etyczne jest podejście do intencji i celu działań moralnych. W utylitaryzmie intencje w ogóle nie są brane pod uwagę w ocenie czynów, ponieważ liczą się tylko ich konsekwencje. Na tym założeniu opierała się m.in. teoria liberalizmu, która głosiła, że ludzie mogą być egoistami, ale dopóki ich działania przynoszą korzyść społeczeństwu, są oceniane pozytywne. Z kolei celem działań moralnych wyznaczanych przez utylitaryzm jest jak największe szczęście jak największej liczby osób. To jednak rodzi problemy związany z mierzeniem tego szczęścia. Trudno bowiem porównać zadowolenie jednej osoby do zadowolenia drugiej, nie mówiąc już o ich sumowaniu ${ }^{34}$.

Z kolei w deontologii dobre uczynki są dobre same w sobie, bez odniesienia do innego celu. Nie są one powiązane ze szczęściem i spełnieniem. Z jednej strony Kant pisał, że zabezpieczenie swojego szczęścia jest obowiązkiem człowieka, ponieważ niezaspokojenie swoich potrzeb prowadzi do uchylania się od obowiązków ${ }^{35}$, ale z drugiej strony uważał, że dążenie do szczęścia nie może być imperatywem kategorycznym, tj. tym, który decyduje o moralności czynu. Moralność czynu oceniamy bowiem na podstawie tego, ile ktoś włożył wysiłku i trudu, by nakierować swoją wolę na spełnienie obowiązku ${ }^{36}$.

${ }_{29}$ Stało się tak m.in. za sprawą Elizabeth Anscombe, która w połowie XX w. podjęła ten temat i spopularyzowała go. W polskiej filozofii etyka cnót jest jednak wciąż mało popularna. N. Szutta, Wspótczesna etyka cnót. Projekt nowej etyki?, Gdańsk 2007, s. 9.

30 N. Szutta, A. Szutta, Wprowadzenie, [w:] N. Szutta, (red.), Wspótczesna etyka cnót: możliwości i ograniczenia, Warszawa 2010, s. 11-12.

$31 \quad$ N. Szutta, Wspótczesna etyka cnót..., dz. cyt., s. 22-35.

32 N. Szutta, A. Szutta, Wprowadzenie..., dz. cyt., s. 12.

33 J. Głowala, Cnoty moralne i kompetencje poznawcze. G. E. M. Anscombe o „connatural knowledge”, [w:] N. Szutta (red.), Wspótczesna etyka cnót..., dz. cyt., s. 103-120.

34 Por. krytyka utylitaryzmu zawarta w: J. Finnis, Prawo naturalne i uprawnienia naturalne, Warszawa 2001, s. 124-132.

35 I. Kant, Uzasadnienie metafizyki moralności, Kęty 2001, s. 16.

36 Tamże, s. 34-48. 
W etyce cnót jest zupełnie odwrotnie: im łatwiej wykonujemy dobry czyn i im większą przyjemność z tego czerpiemy, tym jesteśmy lepszymi ludźmi. Również intencje działań są bardzo ważne. Prawdą jest, że można zrobić dobry uczynek kierując się złymi intencjami, ale należy zauważyć, że taka sytuacja nie sprzyja kształtowaniu cnoty. Tak samo jak przypadkowo dobrze zagrany dźwięk na pianinie nie przyczyni się do postępu w nauce gry na tym instrumencie. Etyka cnót wymaga by zarówno intencje, wykonanie, jak i skutek czynu były dobre. $\mathrm{W}$ aspekcie skutków działania etyka ta jest bliska konsekwencjalizmowi, ale zachodzi między nimi ważna różnica. Na gruncie utylitaryzmu można zrobić wszystko, byle tylko miało to dobre skutki, natomiast w omawianej doktrynie istnieją czyny, których wykonać nie można.

Przewaga etyki cnót nad innymi formami namysłu nad moralnością wynika również z jej przydatności $\mathrm{w}$ innych dziedzinach wiedzy powiązanych bardzo ściśle z praktyką. Jako przykład opisane zostanie jej zastosowanie w pedagogice.

Etyka cnót bardzo silnie wkracza w domenę wychowania i edukacji. Sama istota jej zagadnienia, czyli kształtowanie się charakteru człowieka pretenduje ją do podejmowania zagadnień pedagogicznych. Do tej dziedziny wiedzy należy m.in. analiza procesu nabywania cnót. Jak pisał Wojciech Chudy, każdą osobę cechuje potencjalność, czyli każdy ma pewne możliwości, które może rozwinać. To zaś oznacza pewną niedoskonałość właściwą człowiekowi w momencie narodzin. Jest on bowiem pretendowany do rozwoju i do urzeczywistniania swoich możliwości. Właśnie ta niedoskonałość i cel człowieka, jakim jest dążenie do doskonałości stanowią rację istnienia pedagogiki ${ }^{37}$.

Filozofia klasyczna, z której wywodzi się etyka cnót, jasno określa, czym jest doskonałość człowieka: przejawia się ona w cnotach intelektualnych i moralnych. Człowiek odróżnia się od zwierząt dwoma podstawowymi cechami: rozumnością i wolnością w działaniu. Dlatego, jak pisał Arystoteles, a za nim wielu innych filozofów, aktualizowanie tych dwóch potencjalności, czyli dążenie do poznania i moralne życie wśród innych ludzi (którego najdoskonalszym przejawem jest według Stagiryty uprawianie polityki) wyznaczają cel działania człowieka ${ }^{38}$.

Dla pedagogiki wynikają z tego dwa wnioski: po pierwsze należy kształcić zdolności poznawcze dzieci, a po drugie należy równocześnie wychowywać młodych ludzi w taki sposób, by w przyszłości były zdolne do samodzielnego, dobrego życia. Współcześnie można zauważyć, że kładzie się nacisk na rozwijanie talentów poprzez nauczanie np. języków obcych, gry na instrumentach, śpiewu, zdolności przywódczych, przedsiębiorczości itd., ale jednocześnie zaniedbuje się rozwijanie cnót kardynalnych. Wynikiem tego są częste sytuacje, $\mathrm{w}$ których zdolni ludzie odnoszą sukces w pracy zawodowej, artystycznej, czy politycznej, ale sukces ten staje się dla nich ciężarem osobistym, ponieważ nie potrafią sobie z nim poradzić i wykorzystać go do prowadzenia dobrego życia. Przykładowo, brak cnoty męstwa skutkuje nieodpornością na przeciwności losu i uleganiem negatywnym wpływom; brak cnoty umiarkowania przyczynia się do trwonienia zarobionych pieniędzy, ulegania nałogom, czy prowadzenia hedonistycznego i egoistycznego trybu życia; natomiast brak cnoty sprawiedliwości skutkuje m.in. chciwościa, zawiścia, oszustwami (np. podatkowymi) i nieumiejętnością roztropnego rozporządzania swoim majątkiem i dobrami materialnymi.

Wynika z tego, że tylko edukacja, która jest świadoma konieczności kształtowania cnót i kształcąca je na równi z wiedzą teoretyczną i praktycznymi umiejętnościami, jest w stanie ufor-

37 W. Chudy, Istota pedagogiki personalistycznej, „,Ethos. O Nowej Edukacji” 2006, nr 3 (75), s. 59.

38 Arystoteles, Etyka..., dz. cyt., 1097b-1098a. 
mowaç ${ }^{39}$ człowieka zdolnego poradzić sobie z wyzwaniami, jakie stawia przed nim życie. Należy tu stanowczo podkreślić równoważność tych trzech elementów w wychowaniu (czyli wiedzy, umiejętności i moralności), ponieważ nie jest tak, że człowiek dobry jest człowiekiem mającym dobre intencje i pobudki, ale któremu nic się nie udaje. Podkreślał to m.in. Józef Bocheński pisząc: „najwyższym nakazem etycznym tomizmu jest działać dobrze, bo kto nie działa w ogóle, działać dobrze nie może; a bez działania nie może człowiek osiagnąć swego celu. Wynika z tego wtórnie, że człowiek jest dobry tylko wtedy, gdy może działać, że więc człowiek nawet o najszlachetniejszych intencjach, ale który nie umie, nie potrafi działać, nie jest człowiekiem dobrym. (...) Zapomnienie tej nauki tomizmu doprowadziło do tego, że obecnie mówiąc »dobry człowiek« ma się na myśli raczej istotę nieudolna, o najlepszych chęciach, ale nie umiejącą działać sprawnie" ${ }^{\prime \prime 4}$.

Dla pedagogiki fundamentalne znaczenie ma również proces nabywania cnót. O kontrowersjach, jakie się z nim wiążą była mowa już wcześniej. Niezależnie od nich wydaje się, że rzeczywistość potwierdza tezę filozofii klasycznej, że człowiek nabywa cnoty poprzez przyzwyczajenie, naśladownictwo i autorytet. Widać to chociażby na przykładzie wielu badań wykazujących wpływ środowiska na kształtowanie się dzieci. Szczególnie potwierdza to powszechnie przyjmowana teza o negatywnym wpływie różnego rodzaju sekt, grup, np. przestępczych na wychowanie młodego człowieka. Jest bowiem jasne, że wady kształtują się podobnie jak cnoty - tj. decydujący jest kontekst społeczny ${ }^{41}$. O ile jednak w kształtowaniu cnót znaczenie ma wykonywanie dobrych uczynków i pozytywne wzorce, powstawaniu wad sprzyjają złe uczynki i wzorce negatywne.

Współcześnie na te elementy kładzie nacisk pedagogika uprawiana na gruncie personalizmu. Ten współczesny kierunek filozoficzny akcentujący godność osoby ludzkiej czerpie z filozofii klasycznej, a szczególnie od Tomasza z Akwinu. Elementy etyki cnót są widoczne w pedagogice personalistycznej, mimo że nie zawsze przywołuje się tę nazwę. Katarzyna Olbrycht zatytułowała swoją książkę tak, że można pomyśleć, iż dotyczy ona właśnie etyki cnót - brzmi on: O roli przykładu, wzoru, autorytetu i mistrza w wychowaniu osobowym ${ }^{42}$. Mimo że jest ona pisana w duchu personalizmu, to znajdziemy tam wiele wątków istniejących w filozofii klasycznej. Są to m.in. uznawanie doskonałości, jako celu życia i wychowania; rozumienie autorytetu, jako osoby, która budzi uznanie i zaufanie; konieczność istnienia wzoru osobowego, który jest obierany w celu jego naśladowania i wzorowania się na nim ${ }^{43}$.

Porażka projektu oświeceniowego wyrażająca się w niedoskonałości „etyki encyklopedycznej" oraz niemożność zaproponowania przez nietzscheański genealogizm żadnej pozytywnej teorii są zdaniem Alasdaira MacIntyre'a świadectwem potrzeby jakieś alternatywy. Tą alternatywą okazuje się być teoria znana cywilizacji europejskiej już ponad 2300 lat. Etyka cnót, bo o niej tutaj mowa, ze swoim praktycznym nastawieniem, staje się pomocna nie tylko w abstrakcyjnych rozważaniach na temat dobra moralnego i powinności, ale pomaga w odpowiedzi na pytanie: co jest dobre tu i teraz w tych konkretnych okolicznościach? Czym jest życie szczęśliwe i jak je

39 Słowo „uformować” oddaje z całą swą dosłownością cel pedagogiki uprawianej na gruncie klasycznym. U Arystotelesa forma jest czymś, co stanowi o istocie danej rzeczy i jej cechach. A więc cnota jest formą duszy człowieka, która określa, czy jest on dobry. Tak jak rzeźbiarz nadaje formę posągowi, tak nauczyciel kształtuje formę duszy swojego wychowanka.

40 J. Bocheński, $A B C$ tomizmu, http://www.polskietradycje.pl/article.php?artykul=255, 17.11.2010.

${ }_{41}$ Wiedzieli o tym już myśliciele średniowieczni: Tomasz z Akwinu tłumaczył, że Germanie w czasach Juliusza Cezara nie uważali zabójstwa za nikczemność, co było spowodowane złymi zwyczajami, jaki panował wśród tego ludu. Św. Tomasz z Akwinu, Suma teologiczna, t. 13: Prawo, Londyn 1985, I-II, q. 94, art. 4.

42 K. Olbrycht, O roli przykładu, wzoru, autorytetu i mistrza w wychowaniu osobowym, Toruń 2009.

43 Tamże, s. 26-37. 
osiągnąć? Dzięki temu praktycyzmowi może być ona bazą dla praktycznych rozważań natury pedagogicznej, czy politycznej $j^{44}$.

Zagadnienie etyki cnót jest bardzo bogate, ponieważ obejmuje wiele istotnych tematów, chociażby takich jak klasyfikacja i charakterystyka poszczególnych cnót. Współczesna, anglosaska etyka cnót skupia się głównie na ogólnej i dość abstrakcyjnej charakterystyce cnoty. Z tego względu zadaniem, jakie rysuje się przed odradzającą się etyką cnót, jest analiza poszczególnych trwałych dyspozycji. Oprócz czterech cnót kardynalnych wymienionych w niniejszej pracy istnieje cały szereg cnót pomocniczych wyszczególnionych już przez Tomasza z Akwinu ${ }^{45}$. Perspektywy badawcze tego paradygmatu w filozofii moralnej są więc szerokie i, jak starałem się pokazać w niniejszej pracy, rzeczą pożyteczną i ciekawą jest podjęcie i rozwijanie tego tematu.

\section{BibLIOGRAFIA}

Arystoteles, Etyka Nikomacheiska, [w:] tenże, Dzieła wszystkie, t. 5, Warszawa 1996.

Chudy W., Istota pedagogiki personalistycznej, „Ethos. O nowej edukacji” 2006, nr 3 (75).

Finnis J., Prawo naturalne i uprawnienia naturalne, Warszawa 2001.

Głowala J., Cnoty moralne i kompetencje poznawcze. G. E. M. Anscombe o „connatural knowledge”, [w:] Szutta N. (red.), Wspótczesna etyka cnót: możliwości i ograniczenia, Warszawa 2010.

Głowala M., Dlaczego pewnych rodzajów rzeczy nigdy nie wolno robić? Malum ex genere i bytowość uczynku ludzkiego, „Studia Philosophica Wratislaviensa” 2010, nr 3.

Jaeger W., Paideia. Formowanie człowieka greckiego, Warszawa 2001.

Kant I., Uzasadnienie metafizyki moralności, Kęty 2001.

Kuhn T., Struktura rewolucji naukowych, Warszawa 2009.

Machura P., Etyka cnót a podmiotowość polityczna, [w:] Szutta N. (red.) Wspótczesna etyka cnót: możlizoości i ograniczenia Warszawa 2010

MacIntyre A., Czyja sprawiedliwość? Jaka racjonalność?, Warszawa 2007.

MacIntyre A, Dziedzictwo cnoty, Warszawa 1996.

MacIntyre A, Trzy antagonistyczne wersje dociekań moralnych: Etyka, Genealogia i Tradycja, Warszawa 2009.

Olbrycht K., O roli przykładu, wzoru, autorytetu i mistrza w wychowaniu osobowym, Torun 2009.

Platon, Państwo, Kęty 2003.

Reale G., Historia filozofii starożytnej, t. 2, Lublin 1996

Spaemann R., Kto i za co jest odpowiedzialny? Krytyczne spojrzenie na odróżnienie etyki przekonań i etyki odpowiedzialności, [w:] tenże, Granice. O etycznym wymiarze działania, Warszawa 2006.

Szutta N. (red.), Wspótczesna etyka cnót: możliwości i ograniczenia, Warszawa 2010.

Szutta N., Wspótczesna etyka cnót. Projekt nowej etyki?, Gdańsk 2007.

Szutta N., Szutta A., Wprowadzenie, [w:] Szutta N. (red.) Wspótczesna etyka cnót: możlizości i ograniczenia, Warszawa 2010.

Św. Tomasz z Akwinu, Traktat o cnotach, Kęty 2006.

\section{Netografia}

Bocheński J., ABC tomizmu, http://www.polskietradycje.pl/article.php?artykul=255, 17.11.2010.

Katechizm Kościoła Katolickiego, Poznań 1994, http://www.katechizm.opoka.org.pl/, 12.11.2010.

Św. Tomasz z Akwinu, Suma teologiczna, http://www.katedra.uksw.edu.pl/suma/suma_indeks.htm, 23.11.2010.

44 Na temat politycznego wymiaru etyki cnót zobacz, np: P. Machura, Etyka cnót a podmiotowość polityczna [w:] N. Szutta (red.) Wspótczesna etyka..., dz. cyt., s. 205-227.

45 Św. Tomasz z Akwinu, Suma..., dz. cyt., II-II q. 1-170. 


\section{Słowa kluczowe}

etyka, cnoty, filozofia klasyczna, antropologia filozoficzna, Arystoteles, Tomasz z Akwinu, Alasdair MacIntyre

\section{STRESZCZENiE}

Celem artykułu było przedstawienie etyki cnót, jako odradzającego się paradygmatu w filozofii moralnej. Zaprezentowana została $\mathrm{w}$ nim historia pojmowania cnoty ze szczególnym uwzględnieniem tradycji klasycznej, czyli arystotelesowsko-tomistycznej. Opis klasycznej etyki zawiera m.in. definicję cnoty i klasyfikację cnót. Etyka została przedstawiona w kontekście antropologii filozoficznej. Autor artykułu odwołując się do koncepcji paradygmatów w badaniach moralnych Alasdaira MacIntyre’a dokonał konfrontacji współczesnej etyki cnót z dominującymi współcześnie nurtami badań moralnych oraz wyjaśnił niewspółmierność różnych paradygmatów etycznych. Podjęta została próba wykazania, że etyka cnót, jako odradzający się paradygmat filozofii moralnej, jest w stanie najpełniej i najadekwatniej wyjaśnić i opisać fenomen działań ludzkich o charakterze moralnym.

\section{VIRTUE ETHICS AS A REVIVING PARADIGM OF MORAL PHILOSOPHY}

\section{Keywords}

ethics, virtues, classical philosophy, philosophical anthropology, Aristotle, Thomas Aquinas

\section{Summary}

The aim of this article was to present virtue ethics as a reviving paradigm of moral philosophy. The article presents how virtue was understood in different periods, special attention is paid to classical tradition (Aristotle, Thomas Aquinas). In the description of classical ethics there are, among others, the definition of virtue and the classification of virtues. Ethics is presented in the context of philosophical anthropology. The author refers to the concept of paradigms in Alasdair MacIntyre's research about morality and compares modern virtue ethics to the most popular trends in moral research. He also explains difficulties in comparing different ethical paradigms.

The author is trying to prove that virtue ethics as a reviving paradigm in moral philosophy is the most useful in describing human acting connected with morality. 